\title{
PENGEMBANGAN LOG BOOK PEMBELAJARAN SEPAK BOLA DENGAN PENDEKATAN TAKTIS
}

\author{
Mesnan $^{1}$, Amir Supriadi $^{2}$, Irwansyah Siregar ${ }^{3}$ \\ Fakultas Ilmu Keolahragaan, Universitas Negeri Medan \\ mesnanmed@gmail.com,amircdr@gmail.com,irwansyahsiregar02@gmail.com
}

\begin{abstract}
Abstrak: Penelitian ini bertujuan untuk menghasilkan produk buku ajar model log book pembelajaran sepak bola dengan pendekatan taktis. Penelitian ini merupakan penelitian lanjutan dari penelitian sebelumnya. Berdasarkan analisis dari validator ahli materi, media dan pembelajaran sepak bola bahwa buku ajar yang dikembangkan sudah efisien untuk digunakan dalam proses perkuliahan. Ini karenakan dengan log book pembelajaran sepak bola yang dikembangkan dirancang seperti permainan yang sebenarnya, sehingga proses pembelajaran lebih menarik. Berdasarkan hasil dari validasi ahli materi, ahli media dan uji coba kepada mahassiwa Jurusan PKO FIK Unimed semester I tahun 2019 dapat disimpulkan bahwa buku ajar yang dikembangkan layak untuk dipergunakan dalam perkuliahan sepak bola dasar.
\end{abstract}

Kata Kunci : Log Book, Pendekatan Taktis, Sepakbola.

\begin{abstract}
The study aims to produce a log book product model of football learning with a tactical approach. This research is an advanced study of previous research. Based on the analysis of the material expert validator, media and football learning that the teaching book developed has been streamlined to be used in the course process. It because with a log book of football learning that was developed designed like a real game, so the learning process is more interesting. Based on the results of the validation of material experts, media experts and trials to the students of the Department of PKO FIK Unimed semester I in 2019 can be concluded that the teaching book is developed worthy to be used in the basic soccer lecture.
\end{abstract}

Keywords: Log Book, Tactical approaches, Football

\section{PENDAHULUAN}

Pembelajaran sepak bola yang dilakukan di jurusan Pendidikan Kepelatihan Olahraga (PKO) Fakultas Ilmu Keolahragaan (FIK) Universitas Negeri Medan (Unimed) terdiri dari Sepak Bola Dasar, Pengembangan Keterampilan Sepak Bola, Melatih Kondisi Fisik Sepak Bola, Melatih Teknik dan Taktik Sepak Bola dan Perwasitan Sepak Bola. Matakuliah Sepak Bola Dasar wajib diambil oleh seluruh mahasiswa PKO pada semester I. Matakuliah Pengembangan keterampilan sepak bola merupakan matakuliah pilihan dari 11 matakuliah yang disediahkan pada semester IV. Mahasiswa yang dapat memilih matakuliah penegembangan keterampilan sepak bola adalah mahasiswa yang telah lulus matakuliah sepak bola dasar di semester I.

Bagi mahasiswa yang telah memilih matakuliah pengembangan keterampilan sepak bola, maka mahasiswa tersebut selanjutnya terus akan mengikuti matakuliah spesialisasi sepak bola dari matakuliah pengembangan keterampilan sepak bola sampai pada matakuliah perwasitan. Sehingga mahasiswa yang memilih spesialisasi sepak bola nantinya akan memiliki kompetensi lulusan adalah bidang kepelatihan sepak bola.

Matakuliah sepak bola dasar selama ini yang diajarkan dilapangan menggunakan model yang terpisah dalam proses pembelajarannya, misalnya dalam belajar passing hanya materi passing yang diberikan tanpa adanya penggabungan dengan materi lain. Dengan kata lain pembelajaran yang dilakukan hanya difokuskan kepada penguasaan keterampilan teknik dasar sepak bola semata, sehinga begitu di masuk ke jenjang permainan mahasiswa mengalami kesulitan. Mahasiswa tersebut ketika menguasai bola tidak merasa percaya diri, bingung mau diapakan bola yang ada dikakinya. Mereka tidak berani 
melewati lawan sehingga bola mudah dirampas oleh lawan.

Peneliti meyakini bahwa penyebabnya adalah rendahnya pengalaman mahasiswa dalam mempraktikan pembelajaran yang menggambarkan siatuasi dalampermainan sepak bola yang sebenarnya. Walaupun keterampilan dasar sepak bola yang dimiliki sudah cukup baik, namun mereka belum dapat mengaplikasikan dalam permainan sepak bola yang sebenarnya. Berkaitan dengan permasalahan tersebut, maka dikembangkannya model log book untuk pembelajaran sepak bola dengan pendekatan taktis.

\section{Sepakbola}

Sepak bola adalah permainan beregu yang dimainkan oleh dua tim, dimana setiap tim terdiri dari sebelas orang pemain yang salah satunya adalah seorang penjaga gawang, dengan cara menendangnendang bola, menyundul bola kecuali penjaga gawang yang dapat memainkan bola dengan menggunakan tangan didalam daerah tertentu.

Luxbacher menyatakan bahwa sepak bola adalah pertandingan sepak bola itu dimainkan oleh dua tim yang masing-masing beranggotakan 11 orang. Masing-masing tim mempertahankan gawan dan berusaha menjebol gawang lawan, (Luxbacher, 2004:2). Sedangkan menurut Sucipto dkk sepak bola adalah permainan yang hampir seluruhnya dimainkan menggunakan kaki, kecuali seorang penjaga gawan yang dibolehkan menggunakan lengannya di daerah tendangan hukumannya, (Sucipto Dkk (2000:7).

Diketahui bahwa teknik dasar dalam permainan sepakbola antara lain: menendang, menghentikan bola, menyundul, menggiring, lemparan ke dalam, teknik penjaga gawang. Untuk dapat memiliki keterampilan teknik dasar yang baik diperlukan suatu program latihan yang sistematis, sehingga akan mendapatkan gerakan yang otomatis di dalam bermain.

Sementara itu pada mata kuliah sepak bola dasar di jurusan pendidikan kepelatihan olahraga materi yang diajarkan terdiri dari 8 pokok bahasan, adalah sebagai berikut: 1) Konsep sepak bola, terdiri dari pengertian sepak bola, tujuan permainan sepakbola, tata cara bermain sepak bola, 2) Ball feeling (mengenal bola), terdiri dari teori tentang ball feeling, tujuan ball feeling, latihan ball feeling, 3) Dribbling (menggiring bola), terdiri dari teori tentang dribbling, tujuan dari dribbling, latihan dribbling, 4) Kicking (menendang), terdiri dari teori tentang kicking, tujuan dari kicking, latihan kicking: short passing (umpan pendek), long passing (umpan panjang), crossing (umpan menyilang), shooting (menembak ke gawang), 5) Heading (menyundul bola), terdiri dari teori tentang heading, tujuan dari heading, latihan heading, 6) Throw-in (lemparan ke dalam), terdiri dari teori tentang throw-in, tujuan dari throw-in, latihan throw-in. 7) Goalkepeer (Penjaga Gawang) terdiri dari teori tentang penjaga gawang, tujuan dari penjaga gawang, latihan penjaga gawang.

\section{Log Book Sepak bola}

Log book memiliki pengertian; sebuah buku catatan/dokumen penting siswa untuk mencatat secara detail setiap aktivitas dalam proses pembelajaran yang berisi data diri, data atau informasi kompetensi, daily atau time records, catatan atau uraian terperinci dari kegiatan pembelajaran, refleksi mahasiswa, instrumen penilaian, lembar observasi, angket atau kuesioner, lembar kontrol dosen maupun mentor atau pembimbing industri jika berupa praktik kerja bengkel/industri.

Log book juga dapat dijadikan sebuah instrumen penjamin bagi mahasiswa dalam melakukan praktik dilapangan yang sesuai dengan bidangnya. Diharapkan dengan log book, tidak ada lagi mahasiswa yang melakukan praktik dilapangan yang tidak relevan dengan materi yang diberikanya. Sehingga kegiatan praktik kuliah yang dilakukan benar-benar berdampak dan memberikan nilai tambah meningkatkan keterampilan (skill) pada bidang keahliannya.

Log book sepak bola yang dirancang penulis agar menjadi sebuah dokumen penting yang berisi catatan materi pembelajaran sepak bola yang akan dipelajari oleh mahasiswa. Melalui log book pembelajaran sepak bola ini diharapkan akan membantu dosen dan mahasiswa dalam kegiatan perkuliahan sepak bola dasar. Log book juga berfungsi untuk melatih mahasiswa dalam melakukan praktek pembelajaran dilapangan sehingga mahasiswa bisa belajar secara mandiri.

Log book pembelajaran sepak bola yang dirancang adalah menggunakan pendekatan pembelajaran dengan pendekatan taktis, dimana proses pembelajaran yang dirancang seperti dalam keadaan permainan yang sebenarnya.

Pembelajaran dengan pendekatan taktis dirancang mendorong mahasiswa untuk memecahkan masalah taktik dalam permainan. Masalah taktik pada hakikatnya adalah penerapan keterampilan teknik dalam situasi permainan. Dengan menggunakan pendekatan taktik, mahasiswa lebih dapat memahami kaitan antara teknik dan taktik dalam suatu permainan sehingga mahasiswa akan lebih mudah mengaplikasikannya dalam suatu permainan yang sebenarnya.

Pada permainan sepakbola, keterampilan yang dimiliki setiap pemain tidak terpisahkan dari satu kesatuan tim dan tidak dipergunakan sendiri secara masing-masing. Dalam kemampuan menendang, mengontrol bola dan merebut bola dari lawan harus dapat diselaraskan dengan tujuan yang lain. Dengan kata lain, keterampilan yang dimiliki seorang pemain, tidak akan dapat mencapai tujuan kalau tersendiri. Karena itu banyak kita jumpai, seorang pemain yang 
memiliki keterampilan dan bakat yang baik tidak dimainkan oleh pelatihnya, hal tersebut dikarenakan pemain tersebut tidak dapat bekerja sama dengan teman se-tim dalam pertandingan. Dengan pendekatan latihan taktis akan terjadi proses latihan yang mengutamakan kerjasama tim, karena dalam pendekatan taktis ini adalah permainan yang ditujukan untuk melatih teknis bermain yang disesuaikan dengan kebutuhan pemain atau siswa, sehingga dalam proses latihan/pembelajaran pemain atau anak didik bermain dengan penuh semangat. Sucipto (2001: 3) menyatakan bahwa pendekatan taktis adalah suatu pendekatan pembelajaran keterampilan teknik dan sekaligus di terapkan dalam situasi permainan.

\section{Pengembangan Bahan Ajar}

Buku teks atau buku ajar merupakan bagian dari bahan ajar berbentuk cetak atau tertulis. Tarigan (1986:13) menyatakan buku teks sebagai buku pelajaran dalam bidang studi tertentu yang disusun oleh para pakar dalam bidang tersebut yang digunakan untuk menunjang pembelajaran. Akbar (2010:183) menyatakan buku ajar adalah buku teks yang digunakan sebagai rujukan standar pada materi pelajaran tertentu. Sedangkan Sugiarto (2011) menyatakan buku ajar adalah buku yang disusun untuk kepentingan proses pembelajaran baik yang bersumber dari hasil-hasil penelitian atau hasil dari sebuah pemikiran tentang sesuatu atau kajian bidang tertentu yang kemudian dirumuskan menjadi bahan pembelajaran.

Bahan Pembelajaran merupakan komponen isi pesan dalam kurikulum yang harus disampaikan kepada siswa. Komponen ini memiliki bentuk pesan yang beragam, ada yang berbentuk fakta, konsep, prisnsip/kaidah, prosedur, problema, dan sebagainya. Komponen ini berperan sebagai isi atau materi yang harus dikuasai oleh mahasiswa dalam kegiatan perkuliahan. Ruang lingkup materi pembelajaran telah tersusun secara sistematis dalam struktur organisasi kurikulum dalam hal ini adalah standar isi.
Bahan ajar harus terus mengikuti perkembangan dari ilmu yang berkembang, untuk itu bahan harus terus dikembangkan sesuai kebutuhannya.

Dwiyogo (2004) menyatakan bahwa langkah dari proses pengembangan produk adalah analisis kebutuhan, pengembangan produk, dan uji coba produk. Ketiga langkah tersebut menunjukan urutan waktu dan kegiatan pengembangan. Bahan ajar adalah seperangkat meteri yang disusun secara sistematis baik tertulis maupun tidak tertulis sehingga tercipta lingkungan yang memungkinkan mahasiswa untuk belajar.

Bahan ajar yang kembangkan harus memiliki beberapa keunggulan diantaranya; (1) meningkatkan motivasi dan minat baca, (2) berisikan materi sesuai tuntutan kebutuhan, (3) menggunakan pola belajar fleksibel; (4) dapat dipelajari ulang kapan saja; (5) mengakomodasi berbagai kesulitan; (6) memberikan rangkuman; (7) memiliki gaya penulisan komunikatif (Hunter, 1997)

\section{METODE}

Penelitian ini dilaksanakan di Fakultas Ilmu Keolahragaan Universitas Negeri Medan pada mahasiswa jurusan pendidikan kepelatihan olahraga (PKO) semester I tahun 2019. Penelitian ini merupakan penelitian lanjutan dari penelitian sebelumnya yang menggunakan pendekatan research and Depelopment atau penelitian pengembangan. Model pengembangan diartikan sebagai proses desain konseptual dalam upaya peningkatan fungsi dari model yang telah ada sebelumnya, melalui penambahan komponen pembelajaran yang dianggap dapat meningkatkan kualitas pencapaian tujuan (Sugiarta, 2007:11). Sehingga penelitian ini dilakukan sudah pada tahap validasi desain. Dilanjutkan dengan mengumpulkan data yang dipergunakan untuk perbaikan log book pembelajaran sepak bola dasar.

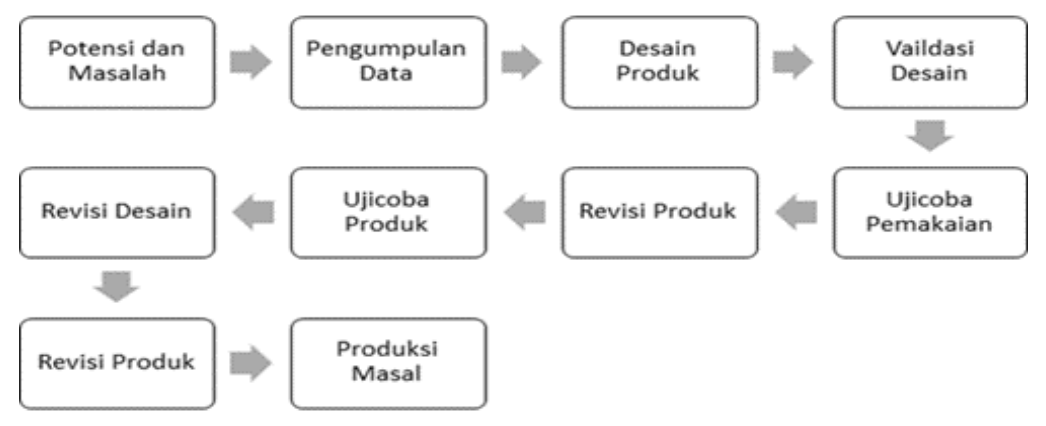

Gambar 1. Alur Penelitian Pengembangan dari Borg dan Gall 
Penelitian ini dilakukan untuk menghasilkan produk log book dalam bentuk bahan ajar pembelajaran sepak bola dengan pendekatan taktis. Aktivitas yang dilakukan adalah langkah-langkah rinci pelaksanaan penelitian pengembangan karena penelitian ini merupakan penelitian lanjutan maka tahapan yang dilakukan sebagai berikut; 1). Validasi log book bahan ajar pembelajaran sepak bola dengan pendekatan taktis oleh ahli materi, ahli media, dan dosen pengampu mata kuliah. Revisi log book bahan ajar pembelajaran sepakbola dengan pendekatan taktis Pengembangan desain log Book bahan ajar pembelajaran sepakbola dengan pendekatan taktis dan instrumen Pengumpulan data atau informasi awal, 2) Uji coba skala kecil, 3) Revisi log book bahan ajar pembelajaran sepakbola dengan pendekatan taktis oleh peneliti, 4) Uji coba skala Besar, 5) Revisi log book bahan ajar pembelajaran sepakbola dengan pendekatan taktis, 6) Produk akhir log book bahan ajar pembelajaran sepak bola dengan pendekatan taktis.

\section{HASIL DAN PEMBAHASAN}

Berdasarkan hasil uji coba yang dilakukan terhadap 63 mahasiswa jurusan PKO semester I tahun 2019 diperoleh hasil bahwa untuk materi
Konsep sepak bola terdapat 60 mahasiswa menyatakan bahwa buku ajar yang dikembangkan mudah untuk dipahami dan dipelajari sedang 3 orang mahasiswa lainnya menjawab tidak. Materi Ball Feeling terdapat 55 mahasiswa menyatakan bahwa buku ajar yang dikembangkan mudah untuk dipahami dan dipelajari sedang 8 orang mahasiswa lainnya menjawab tidak. Materi dribbling terdapat 58 mahasiswa menyatakan bahwa buku ajar yang dikembangkan mudah untuk dipahami dan dipelajari sedang 5 orang mahasiswa lainnya menjawab tidak.

Materi Ball Feelin Kicking terdapat 56 mahasiswa menyatakan bahwa buku ajar yang dikembangkan mudah untuk dipahami dan dipelajari sedang 7 orang mahasiswa lainnya menjawab tidak. Materi heading terdapat 57 mahasiswa menyatakan bahwa buku ajar yang dikembangkan mudah untuk dipahami dan dipelajari sedang 6 orang mahasiswa lainnya menjawab tidak. Materi throw-in terdapat 57 mahasiswa menyatakan bahwa buku ajar yang dikembangkan mudah untuk dipahami dan dipelajari sedang 6 orang mahasiswa lainnya menjawab tidak. Materi goalkeeper terdapat 58 mahasiswa menyatakan bahwa buku ajar yang dikembangkan mudah untuk dipahami dan dipelajari sedang 5 orang mahasiswa lainnya menjawab tidak. Data hasil Uji coba buku ajar dapat dilihat pada tabel 1 .

Tabel 1. Hasil Uji Coba Kelompok Besar Buku Ajar Kepada Mahasiswa Semester I PKO FIK Unimed

\begin{tabular}{|c|c|c|c|c|}
\hline \multirow[t]{2}{*}{ No } & \multirow[t]{2}{*}{ Materi } & \multirow[t]{2}{*}{ Pertanyaan } & \multicolumn{2}{|c|}{$\begin{array}{c}\text { Jumlah Mahasiswa yang } \\
\text { Menjawab }\end{array}$} \\
\hline & & & Ya & Tidak \\
\hline 1 & Konsep Sepak bola & Mudah Di Pahami dan dipelajari & 60 & 3 \\
\hline 2 & Ball Feeling & Mudah Di Pahami dan dipelajari & 55 & 8 \\
\hline 3 & Dribbling & Mudah Di Pahami dan dipelajari & 58 & 5 \\
\hline 4 & Kicking & Mudah Di Pahami dan dipelajari & 56 & 7 \\
\hline 5 & Heading & Mudah Di Pahami dan dipelajari & 57 & 6 \\
\hline 6 & Throw-in & Mudah Di Pahami dan dipelajari & 57 & 6 \\
\hline 7 & Goal Kepeer & Mudah Di Pahami dan dipelajari & 58 & 5 \\
\hline & & Jumlah & 395 & 46 \\
\hline & & Persentase & $89,6 \%$ & $10,4 \%$ \\
\hline
\end{tabular}

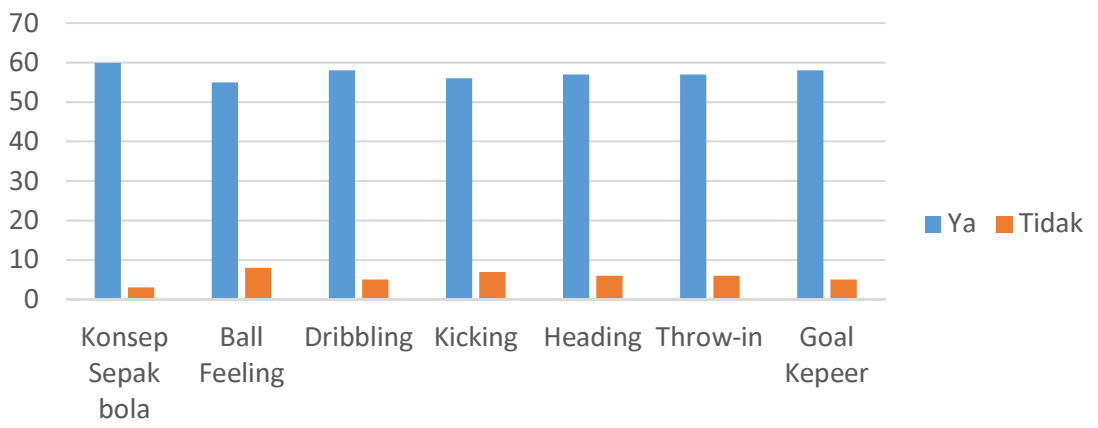

Gambar 2. Histogram Hasil Uji Coba Buku Ajar 


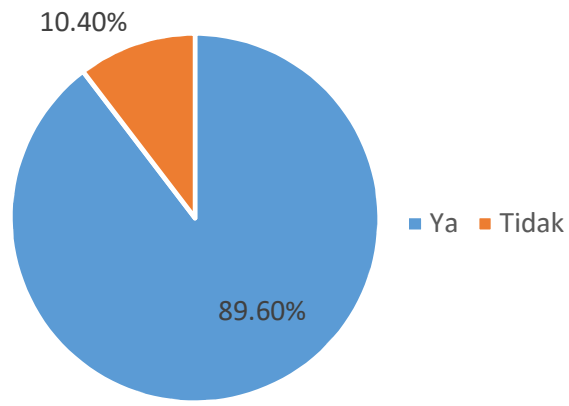

Gambar 3. Grafik Persentase Hasil Uji Coba Buku Ajar

Sementara persentase dari hasil uji coba buku ajar yang dikembangkan kepada mahasiswa jurusan PKO FIK Unimed semester I didapat 89,60 \% mahasiswa menyatakan bahwa buku ajar yang dikembangkan mudah di pahami dan untuk dipelajari, sedangkan $10,40 \%$ menyatakan tidak.

Berdasarkan hasil dari validasi ahli materi, ahli media dan uji coba kepada mahasiswa Jurusan PKO FIK Unimed semester I tahun 2019 dapat disimpulkan bahwa buku ajar yang dikembangkan layak untuk dipergunakan dalam perkuliahan sepak bola dasar. Dengan artian buku ajar log book pembelajaran sepak bola dasar dengan pendekatan taktis dapat dicetak untuk diperbanyak.

\section{KESIMPULAN}

Matakuliah sepak bola dasar selama ini yang diajarkan dilapangan menggunakan model yang terpisah dalam proses pembelajarannya sehingga perlu pembaharuan dalam proses perkuliahannya. Maka disini peneliti melakukan suatu pengembangan buku ajar yang berupa log book dengan pendekatan taktis. Setelah melakukan validasi oleh para pakar dan diujicobakan kepada mahasiswa jurusan PKO FIK Unimed semester I. Berdasarkan hasil dari validasi ahli materi, ahli media dan uji coba kepada mahassiwa Jurusan PKO FIK Unimed semester I tahun 2019 dapat disimpulkan bahwa buku ajar yang dikembangkan layak untuk dipergunakan dalam perkuliahan sepak bola dasar. Dengan artian buku ajar log book pembelajaran sepak bola dasar dengan pendekatan taktis dapat dicetak untuk diperbanyak dan sebarluaskan kepada semua yang membutuhkan buku ajar sepak bola ini.

\section{REFERENSI}

Akbar, S. 2011. Pengembangan Kurikulum dan Pembelajaran Ilmu Pengetahuan Sosial. Yogyakarta: Cipta Media.

Hunter, Madeline. 1997. Improve Instruction. California: TIP Publication.
Luxbacher, Joseph A. 2004. Sepakbola, terjemahan Gusta Wibawa , Jakarta : Raja Grafindo Persada

Majid. Abdul. 2012. Perencanaan Pembelajaran Mengembangkan Standar Kompetensi Guru. Bandung: PT Remaja Rosdakarya.

Martinez, Joseph G.R dan Martinez, Nancy. 2007. Teacher Effectivenes and Learning for Mastery. Juournal of educational Research. http://www.Questia.com

Sucipto. 2001. Pendekatan Keterampilan Taktis dalam Pembelajaran Pencak Silat Konsep \& Metode, Jakarta: Depdiknas

Sugiarta, Awandi Nopyan. 2007. Pengembangan Model Pengelolaan Program Pembelajaran Kolaboratif Untuk Kemandirian Anak Jalanan Di Ru mah

Singgah (Studi Terfokus di Rumah Singg ak Kota Bekasi). Desertasi tidak diterbitkan. Bandung: PPS UPI

Sugiarto. 2011. Landasan Pengembangan Bahan Ajar. Materi Workshop Penyusunan Buku Ajar Bagi Dosen Politeknik Kesehatan Kemenkes Semarang.

Sukmadinata. 2005 Metode Penelitian, Bandung: PPs UPI dan PT Remaja Rosdakarya.

Tarigan, D \& Tarigan. 1986. Teknik Pengajaran Keterampilan Berbahasa. Bandung: Angkasa.

Tomoliyus. 2001. Pendekatan Keterammpilan Taktis dalam Pembelajaran Bola Basket, Jakarta: Depdiknas.

Wasis D. Dwiyogo. 2004. Konsep Penelitian dan Pengembangan. Lokakarya Metodologi Penelitian, Jurusan Kepembelajaran FIK Unesa. Malang: UNM 